\title{
FRESHWATER DIATOMS ON SUB-ANTARCTIC MACQUARIE ISLAND: AN ECOLOGICAL SURVEY OF 14 LAKES
}

\author{
by T. P. McBride
}

(with two text-figures, three tables and three appendices)

\begin{abstract}
McBride, T.P. 2009 (11:xii): Freshwater diatoms on sub-Antarctic Macquarie Island: an ecological survey of 14 lakes. Papers and Proceedings of the Royal Society of 'lasmania 143(2): 73-81. https://doi.org/10.26749/rstpp.143.2.73 ISSN 0080-4703. Department of Biological Sciences, Macquarie University, New South Wales 2109 , Australia.
\end{abstract}

\begin{abstract}
A survey of the diatom (Bacillariophyceae) populations in 14 lakes and ponds on sub-Antarctic Macquarie Island identified 102 species from 34 genera, including species considered endemic to the sub-Antarctic region. Multivariate analysis of the diatom communities divided the lakes into two broad groups; oligotrophic plateau lakes dominated by species including Brachysira exilis, Fragilaria capucina var. gracilis, Psammothidium abundans, Ps. confusum and Ps. confusum var. atomoides, and lowland peat-based lakes dominated by species including Fragilaria pulchella, Planothidium lanceolatum and Pl. quadripunctatum. Factors relating to lake elevation rather than water $\mathrm{pH}$ or conductivity appeared to have most influence on the lake diatom communities.
\end{abstract}

Key Words: Macquarie Island, sub-Antarctic, diatoms, Bacillariophyceae.

\section{INTRODUCTION}

Sub-Antarctic Macquarie Island (fig. 1) is located at $54^{\bullet} 38^{\prime} \mathrm{S}$, $158^{\circ} 53^{\prime}$ E, approximately midway between Australia and the Antarctic continent within the sub-Antarctic biogeographical zone, a region of islands in the southern Atlantic and Indian oceans. Macquarie Island is politically part of Tasmania and is listed as a World Heritage Area because of its geological and natural significance. The island is part of an undersea ridge raised above the surface by tectonic action and the nearest large land masses are mainland Tasmania, approx $1470 \mathrm{~km} \mathrm{NNW,} \mathrm{and} \mathrm{New}$ Zealand approx $1130 \mathrm{~km} \mathrm{NE}$ (Commonwealth of Australia 1996). An undulating plateau generally 200-250 m above sea level covers most of the island's $34 \times 5.5 \mathrm{~km}$ area. The climate is moist, windy and cool (yearly average $5^{\circ} \mathrm{C}$ ) with low seasonal variation (Selkirk et al. 1990). Numerous lakes and extensive waterlogged areas are present. The lake waters are of low salinity, which is mostly derived from sea spray (Tyler 1972). This paper presents findings from the first extensive survey of the diatoms in freshwater habitats on Macquarie Island and compares these findings with surveys on other sub-Antarctic islands. Diatoms are unicellular algae characterised by silica cell walls consisting of two overlapping halves called valves. Diatom taxonomy is based on the shape and patterning of the valves rather than the living forms. Diatoms inhabit marine, freshwater and moist terrestrial environments throughout the world. The structure of diatom comm unities is sensitive to water quality and diatoms can provide a powerful tool for assessing and monitoring water quality and environmental conditions. The presently available literature on sub-Antarctic diatoms identifies floras containing a number of endemic taxa and many similarities exist between diatom floras of widely scattered islands (Van de Vijver \& Beyens 1999). Diatom studies are available for Kerguelen Island: (Germain 1937, Bourrelly \& Manguin 1954, Le Cohu 1981, Le Cohu \& Maillard 1983, 1986, Van de Vijver et al. 1998); Crozet Isles (Pierre 1977, Van de Vijver \& Beyens 1999, Van de Vijver et al. 2002); and Heard Island (Van de Vijver et al. 2004). The available publications on Macquarie Island diatoms (Bunt 1954, Evans 1970, Keenan 1995, McBride
\& Selkirk 1999, McBride et al. 1999 and Saunders et al. 2008) do not include a comprehensive illustrated flora.

\section{SAMPLES AND ANALYTICAL METHODS}

Rock scrapings, submerged vegetation and bottom sediment were collected from 14 lakes and ponds (table 1) during summer visits to Macquarie Island (details in appendix 1). Samples of 15-25 ml were taken within a 10-40 cm depth range near the shore and preserved with formaldehyde until processed. The submerged vascular plant Myriophyllum triphyllum Orchard was present in most lakes and was included in collections as a diatom substrate. Rock surfaces for scraping were not available in the peat-based lakes. Water $\mathrm{pH}$, conductivity and temperature were measured at the time of sample collection and water samples were taken for later analysis. Figure 1 shows the location of the lakes and ponds from which collections were made. Of the 26 named water bodies on the island, the 14 sampled included representative types spanning most of the island. Water bodies on Macquarie Island are variously named as lake, lagoon, pond or tarn but for simplicity in this paper the water bodies sampled are all referred to as lakes. Evans (1970) proposed a classification system for Macquarie Island water bodies that can be used to categorise the lakes in this study. Duck Lagoon, Green Gorge Tarn, Handspike Tarn and Langdon Point Pond are type "a", peat-based ponds on the coastal terrace; Brothers Lake, "S" Pond, Skua Lake and Square Lake are type "b" ponds occurring on highmoor peat beds on the plateau; Lake Ainsworth, Ifould Lake, Major Lake, Prion Lake, Pyramid Lake and Tulloch Lake are type "c" lakes occurring on tundra soils on the plateau. Major Lake is the island's largest lake, having an area of $0.5 \mathrm{~km}^{2}$ and maximum depth of $16 \mathrm{~m}$. " $\mathrm{S}$ " Pond is tiny compared with the plateau lakes (max width about $10 \mathrm{~m}$, max depth about $40 \mathrm{~cm}$ ) but was included in the sampling program because Evans (1970) used it as a study site and listed its diatom flora.

To prepare the diatom material for examination, about $20 \mathrm{ml}$ of $34 \%$ hydrogen peroxide was added to the sample in a covered vial and left at room temperature for at least a week to partially oxidise the material without violent 
TABLE 1

Sampling sites and number of samples collected per year from 1988 to 1993

\begin{tabular}{|c|c|c|c|c|c|c|c|c|c|c|c|c|c|c|}
\hline Year & 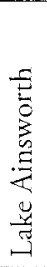 & $\frac{\frac{\mathscr{y}}{\pi}}{\frac{0}{0}}$ & $\begin{array}{c}5 \\
0 \\
8 \\
3 \\
3 \\
0 \\
0 \\
0 \\
0\end{array}$ & $\frac{\vec{G}}{\vec{E}}$ & 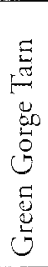 & 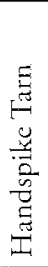 & 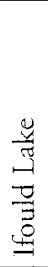 & 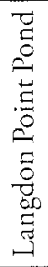 & 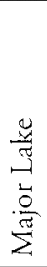 & 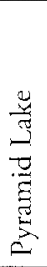 & 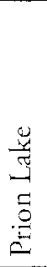 & 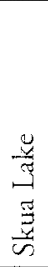 & 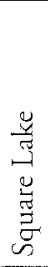 & 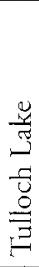 \\
\hline 1988 & 2 & 3 & 1 & & 1 & & & & 3 & 2 & & 4 & & 2 \\
\hline 1989 & 5 & 3 & 8 & 2 & 1 & 2 & 3 & 2 & 3 & - & 1 & 3 & & \\
\hline 1990 & & 2 & 4 & 1 & 1 & & & & 1 & 1 & 1 & & 2 & 2 \\
\hline 1991 & & 1. & 2 & & 1 & & & & & & 1 & & 2 & \\
\hline 1992 & & 3 & & 1 & & & & & & 2 & 2 & & 4 & 4 \\
\hline 1993 & 1 & & & & 1 & & & & 2 & & & & & 2 \\
\hline
\end{tabular}

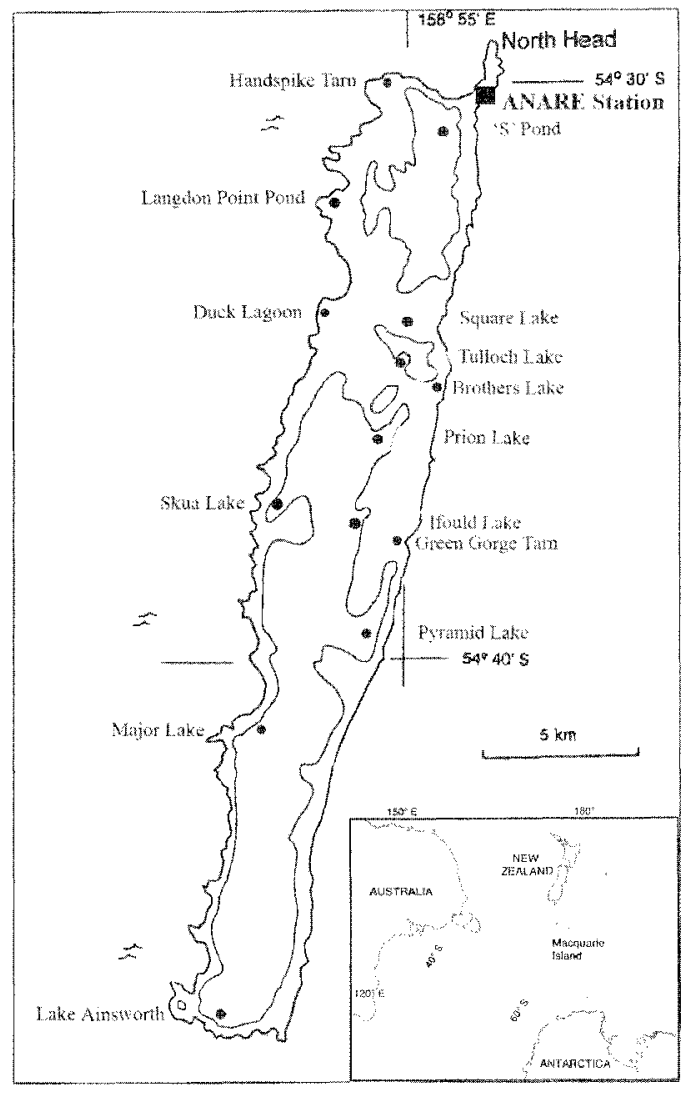

FIG. 1 - Macquarie Island, showing locations of lakes and ponds that were sampled.

reaction. Oxidation was completed by placing the vial in an oven at $100^{\circ} \mathrm{C}$ for 15 minutes. The cleared diatom valves were allowed to settle on to a cover slip from suspension then mounted in Naphrax on a microslide (McBride 1988). At least 300 valves were identified and counted on each microslide. Species were identified at $1000 \mathrm{x}$ magnification under a light microscope (Olympus Vanox) fitted with Nomarski interference contrast. The principal taxonomic reference was that of Van de Vijver et al. (2002) because of its sub-Antarctic specificity and status as the only comprehensive illustrated flora for a sub-Antarctic island. Other taxonomic references were Krammer \& Lange-Bertalot (1997), Germain (1981), Le Cohu (1981), Le Cohu \& Maillard (1983, 1986) and John (1983). Recent revisions of diatom taxonomy have been incorporated to maintain consistency with Van de Vijver et al. (2002) and these changes considerably rearrange the genera, e.g., Achnanthidium, Planothidium and Psammothidium have been separated from Achnanthes, and Adlafia, Diadesmis, Naviculadicta, Lecohuia, Eolimna, Geissleria, Luticola have been separated from Navicula. The similarity of the diatom community in the same lake in different years was assessed using Twinspan ordination (Minchin 1990), where the samples were arranged in an order determined by the relative abundance of each diatom species in the sample (appendix 1 lists samples in the Twinspan order). For six of the lakes ("S" Pond, Major Lake, Skua Lake, Duck Lagoon, Handspike Tarn and Langdon Point Pond) the samples from each lake grouped together without mingling with the samples from other lakes. For the other lakes some intermingling of samples from different lakes occurred but generally the samples from each lake were grouped together. Therefore it was considered appropriate to combine the data from each lake for further analysis. Multivariate analysis using Decorana (Minchin 1990) was used to align the lakes along theoretical environmental gradients based on similarities in their diatom communities.

\section{RESULTS}

Over 32000 diatom valves were counted in samples from the 14 lakes and a total of 102 species in 34 genera were identified (details in appendix 2). Figure 2 shows the arrangement of the lakes when Decorana Axis 1 is plotted against Axis 2. Table 2 and appendix 3 show the major species observed in each lake with the order of the lakes according to Axis 1 of the Decorana ordination. The high Eigenvalue of Axis 1 (0.79) suggests this ordering of the lakes relates to a strong environmental gradient. Four of the plateau lakes - Lake Ainsworth, Prion Lake, Pyramid Lake and Tulloch Lake - are grouped together, as are Major Lake and Skua Lake. Ifould Lake and Square Lake are placed towards the group of coastal terrace lakes. The coastal terrace lakes - Brothers Lake, Duck Lagoon, Green Gorge Tarn, Handspike Tarn and Langdon Point Pond - form a closely spaced group suggesting their communities are very similar. " $\mathrm{S}$ " Pond is an outlier especially when its position on Axis 2 is taken into account. 


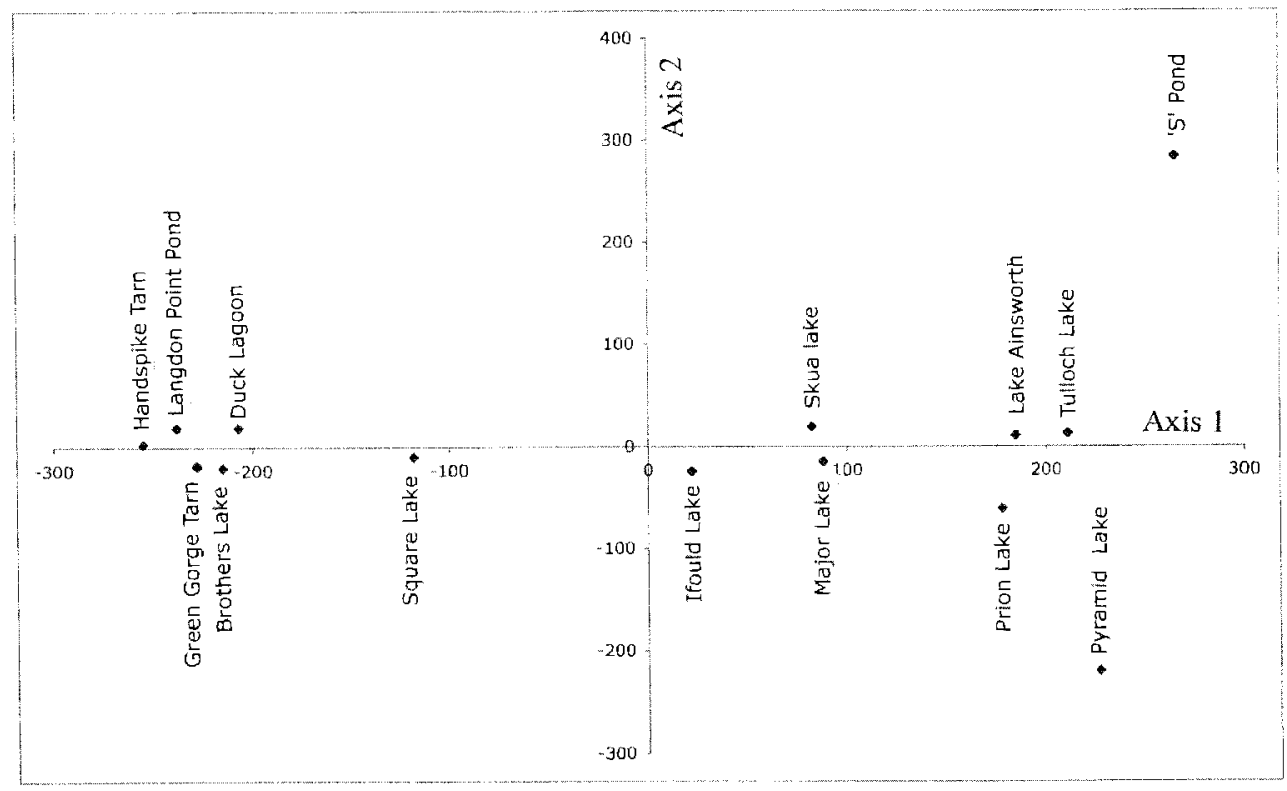

FIG. 2 - Arrangement of lake diatom communities along environmental gradients. Decorana Axis 1 (Eigenvalue 0.79) plotted against Axis 2 (Eigenvalue 0.49) showing the positions of lake diatom communities in this theoretical space. All species were included and data were the relative abundance of each species without transformation. These ordination axes represent environmental gradients that influence the structure of the diatom communities.

TABLE 2

Diatom species in Macquarie Island lakes

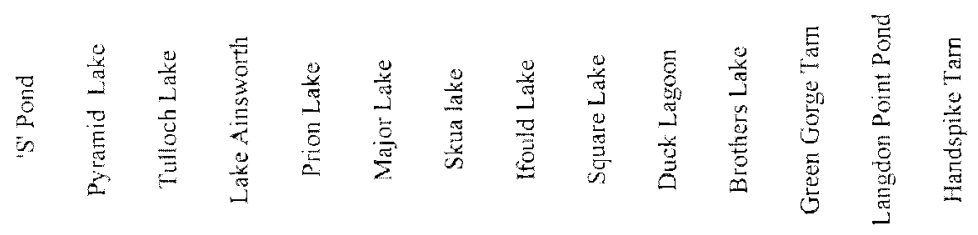

\begin{tabular}{|c|c|c|c|c|c|c|c|c|c|c|c|c|c|c|}
\hline Achnanthidium minutissimum & - & - & - & - & - & $\$+4$ & H\# & 出特抹 & $\#$ & - & & - & & \\
\hline Amphora coffecreformis & & & - & & - & - & $\#$ & - & $\# \#$ & & - & - & & \\
\hline Aulacoseira distans & H\#\# & -. & - & & & & -. & - & & & & & & \\
\hline Brachysira exilis & $\#$ & $\#$ & 些管 & 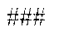 & $\#$ & $\frac{1}{f t}$ & - & & - & & & & & \\
\hline Cocconeis placentula & & & - & & & - & - & \#H & $H+$ & 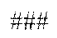 & $H \#$ & H保 & & \\
\hline Cymbella microcephala & & & & & - & \# & \# & $\# \#$ & $\#$ & & - & & & \\
\hline Diatomella balfouriana & & - & - & & & $\#$ & HA & 种井 & & - & & & & \\
\hline Ennotia curvata & & 侍样 & - & - & $\#$ & & & & - & & - & & & - \\
\hline Fragilaria capucina var vaucheriae & - & - & - & 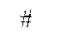 & & $4+4$ & \#将 & $\#$ & Hith & 㻆能 & H & - & H & \\
\hline Fragilaria capucha var gracilis & & H斩 & H\#H & H\#借 & H耕 & HH & HH & & - & & & & & \\
\hline Fragilaria capucina var rumpens & & & & H & & + & & \# & & - & & & & \\
\hline Fragilaria exigua & & & & - & & & & & - & \#\#茾 & & & $f: H$ & \\
\hline Fragilaria pulchella & - & - & - & - & - & $\#+\#$ & - & \#斯 & \#\# & $\#$ & \#\# & H萧刑 & - & 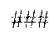 \\
\hline Gomphonema affine & & & & - & - & - & & & 弁 & - & 禁持H & - & - & \\
\hline Gomphonema intricatum & & - & - & - & - & - & $\frac{H}{\forall f}$ & & - & - & - & & & \\
\hline Lecohuia geniculata & - & - & - & - & HA & - & - & - & & & & & & \\
\hline Naviculadicta seminulum & - & - & - & - & $\#$ & - & - & - & - & - & - & & 耕出 & $\#$ \\
\hline Nitzschia gracilis & - & - & & . & & * & & & \#\#\# & $\#$ & $H \#$ & & & \\
\hline Planothidium aneri & - & - & - & & - & - & - & $\#$ & & & & - & & \\
\hline Planothidium deliculatum & & & & & & & & & - & \#\# & & & 葓茾梊 & - \\
\hline Planothidium lanceolatum & & & & - & & - & - & - & - & 茾 & 萧 & Hy & 岀措 & HHH \\
\hline Planothidium quadripunetanm & & & - & - & - & - & - & - & - & \#\# & $H$ & $\#$ & 苏刑茾 & 茾茾 \\
\hline Psammothidizm abundans & \#隹护 & - & H开床 & - & - & $\#$ & $4+4$ & - & - & - & - & - & & \\
\hline Psammothidium confusum & - & 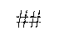 & $H F$ & $\#$ & \#H+H & \# & - & 枅斗H & - & & - & - & - & \\
\hline Psammothidium confustum var atomoides & & 株禁势 & H校筆 & 出 & \#洋 & \# & - & $\#$ & & - & - & - & - & - \\
\hline Psammothidizm oblongellum & - & & - & & - & - & - & & & - & & & $\#$ & \\
\hline Psammothidium therezienii & H\#\# & & & - & - & & - & - & & & & & & \\
\hline Staurosira pinnata & & & & & & - & $\#$ \#H & & - & 专井 & - & & - & \\
\hline No of species observed & 26 & 37 & 41 & 39 & 34 & 49 & 47 & 42 & 42 & 43 & 28 & 22 & 20 & 11 \\
\hline
\end{tabular}

Relative abundances of major species and total species numbers in each lake. The symbol \#\#\# represents $>10 \%$ relative abundance, \#\# represents 5-10\%, \# represents $2-5 \%$, - represents $<2 \%$. 


\section{DISCUSSION}

On Macquarie Island, as elsewhere in the sub-Antarctic region, araphid species (without a raphe slit on either valve face), especially Fragilaria, and monoraphid species (having a raphe slit on one valve face), especially Achnanthes and the genera formerly within Achnanthes formed major, sometimes dominant members of the lake diatom communities. Van de Vijver \& Beyens (1999) consider a number of species (revised names in parentheses) to be confined to the sub-Antarcticzone: Achnanthes confusa (Psammothidium confusum), A. germainii (Ps. germainii), Diatomella hustedtii (D. balfouriana), Pinnularia microstauron var. elongata (Pi. subantarctica var. elongata). These species are well represented on Macquarie Island, reinforcing the view that a characteristic freshwater diatom flora exists in the sub-Antarctic, even though confined to small islands separated by long ocean distances. Saunders et al. (2008) identified 208 diatom species from 34 genera in samples from 50 ponds and lakes on Macquarie Island, compared to 102 species from 34 genera identified in the present study. The larger number of samples examined by Saunders et al. (2008) could be expected to reveal more species. If sampling had included soils and bogs a highet number of species would be expected in both studies. For example, an endemic species, Gomphonema isabellae, was later identified from a mire adjoining Green Gorge Tarn (Van de Vijver \& McBride 2006) but was not observed in the samples forming the basis of this paper. It is difficult to comment on the higher number of species reported by Saunders et al. (2008) without seeing the full species list on which the number is based. On Île de la Possession (Crozet Archipelago) Van de Vijver \& Beyens (1999) identified 210 diatom taxa from 127 lake and stream samples. The most abundant genera were Fragilaria, Achnanthes and Navicula, the same genera found on Macquarie Island (including the revised genera formerly within Achnanthes and Navicula). The higher species diversity on Île de la Possession may be explained by the greater habitat diversity, notably $\mathrm{pH}$ values ranging from 4.9 to 10 , compared with values from 6.4 to 9.7 in the 14 Macquarie Island lakes examined in this study. Saunders et al. (2008) found a broader $\mathrm{pH}$ range of 5.5-9.95 by sampling 50 Macquarie Island lakes.

Some species, such as Achnanthes clevei, Amphora coffeaeformis, and Cocconeis placentula, are present or abundant on Macquarie Island but apparently absent from Kerguelen or Crozet islands. Only one species, Fragilaria pulchella, was observed in every lake. Four species were observed only in plateau lakes: Brachysira exilis, Psammothidium therezienii, Lecohuia geniculata, Aulacoseira distans, while one species, Planothidium deliculatum, was observed only in coastal terrace lakes. The diatom communities in the nine plateau lakes were generally more diverse with an average of 40 species, compared with the five coastal terrace lakes with an average of 24 species. The community of "S" Pond was distinct in having the centric species, Aulacoseira distans, as a major component. Its outlier status in the ordination matches its physical situation as a small, shallow and peat-based water body located at $220 \mathrm{~m}$ on the plateau. The other lakes at elevations about $200 \mathrm{~m}$ are large type "c" lakes. Psarnmothidium confusum, Ps. confusum var. atomoides and Fragilaria capucina var. gracilis typify the plateau lake communities. Planothidium lanceolatum, Pl. quadripunctatum and F pulchella typify the coastal terrace lake communities (table 2). Two of the $F$ capucina morphotypes proposed by Van de Vijver et al. (2002) appear to have different habitat preferences: the slender form, F. vaucheriae var. gracilis (formerly $F$ vaucheriae var. longissima), is abundant only in type " $\mathrm{c}$ " plateau lakes whereas $F$ vaucheriae var. vaucheriae, while present in the plateau lakes, is abundant mostly in type "a" coastal terrace lakes. Planothidium deliculatum was abundant only in the two lakes, Duck Lagoon and Langdon Point Pond, which had the highest conductivities. Brachysira exilis appears confined to the plateau lakes. Eunotia curvata was abundant in Pyramid Lake, which had the lowest $\mathrm{pH}$.

There is broad agreement in the number of species observed in this study (shown in parentheses) with the number of species observed by Evans (1970) who listed a total of 84 (102) species in five ponds and lakes, 41 (34) species in Prion Lake, 25 (26) species in "S" Pond, and 37 (43) species in Duck Lagoon. The study by Bunt (1954) examined terrestrial diatoms and is not directly comparable. Comparison between environmental variables and lake position on Decorana Axis 1 (table 3) suggests the lake diatom communities are influenced to some extent by silica concentrations and by conductivity and $\mathrm{pH}$. Silica concentrations are lowest in the plateau lakes and increase in a clear pattern along the axis to the coastal lakes suggesting a strong effect on the diatom communities. Conductivity also generally increases along the axis. The pattern of $\mathrm{pH}$ along the axis shown is less clear and shows highest values near the centre suggesting $\mathrm{pH}$ has less influence than silica concentrations and conductivity. Saunders et al. (2008), using a larger data set, found conductivity, $\mathrm{pH}$ and silicate concentrations made independent, significant contributions to explaining variation in the species data.

For most lakes, nitrate concentrations were below the detection limit, limiting the discrimination available. Within the group of similar coastal terrace lakes, Duck Lagoon and Brothers Lake were below detection limits while Langdon Point Pond was over 60 times the detection limit, suggesting nitrate concentrations were not a strong factor. A further consideration is that the values shown in table 3 are a "snapshot" and represent lake water quality at one point in time or the average of a limited number of readings. Water conductivity and nitrate concentrations in coastal terrace lakes are highly variable due to seawater ingress during storms and seasonal inputs from seal wallows and penguin rookeries (Evans 1970).

The environmental gradient corresponding to the order of lake communities along Axis 1 (table 3) seems to be related to lake elevation. There is a clear progression from the type "c" plateau lakes with elevations over $140 \mathrm{~m}$ asl through the type "b" plateau lakes $(75-99 \mathrm{~m}$ asl) to the type "a" coastal terrace lakes. The environmental gradient linked to elevation that is influencing the communities could be temperature, a parallel situation to the terrestrial vegetation on Macquarie Island which shows marked altitude zonation. Based on thermograph data, Evans (1970) reports temperatures in Duck Lagoon on the coastal terrace were consistently several degrees higher than those for Prion Lake or "S" Pond on the plateau. This difference may be sufficient to affect the structure of the diatom communities in lakes at different elevations.

In addition to temperature, elevation affects the inputs of nutrients and ions from sea spray, which decrease with distance from the west coast due to the prevailing westerly weather patterns (Saunders et al. (2008)). The resultant changes in water chemistry could also produce an elevationrelated pattern in lake diatom communities. 
TABLE 3

Lake water quality and elevation

\begin{tabular}{|c|c|c|c|c|c|c|c|c|c|c|c|c|c|c|}
\hline & $\begin{array}{l}\bar{g} \\
\overline{0} \\
\underline{\omega}\end{array}$ & 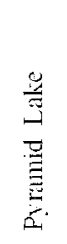 & 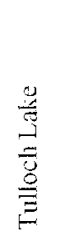 & 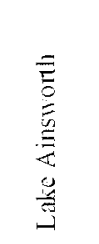 & 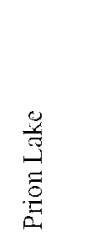 & $\begin{array}{l}\frac{y}{3} \\
\frac{0}{3} \\
\frac{5}{2}\end{array}$ & 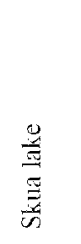 & 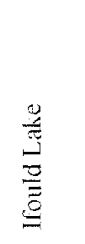 & 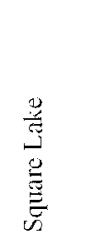 & 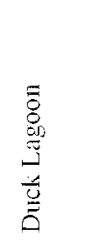 & 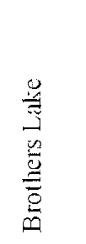 & 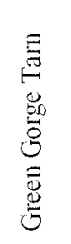 & 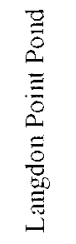 & 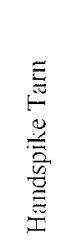 \\
\hline pH measured Oct/Nov 1988 & & 6.3 & & 6.5 & & 7.1 & 7.5 & & 9.6 & 7.9 & 9.1 & 7.5 & & 7.0 \\
\hline pH measured Nov/Dec 1989 & 7.3 & & & 7.2 & 7.2 & 7.4 & 8.1 & 8.0 & 9.9 & 9.7 & 8.4 & 8.2 & 7.1 & 7.1 \\
\hline pH measured Dec 1990 & & 6.5 & 6.7 & & 7.6 & 7.5 & & & 9.5 & 8.1 & & 7.6 & & \\
\hline pH measured Dec 1992 & & & 6.6 & & & & & & 9.6 & 9.0 & & & & \\
\hline Average pH & 7.3 & 6.4 & 6.7 & 6.9 & 7.4 & 7.3 & 7.8 & 8.0 & 9.7 & 8.7 & 8.8 & 7.8 & 7.1 & 7.1 \\
\hline Conductivity $(\mu \mathrm{S} / \mathrm{cm})$ measured Oct/Nov 1988 & & 140 & & 200 & & 240 & 270 & & 300 & 850 & 250 & 230 & & 610 \\
\hline Conductivity $(\mu \mathrm{S} / \mathrm{cm})$ measured Nov/Dec 1989 & 360 & & & 210 & 170 & 270 & 285 & 190 & 305 & 960 & 250 & 240 & 1240 & 740 \\
\hline Conductivity $(\mu \mathrm{S} / \mathrm{cm})$ measured Dec 1990 & & 98 & 121 & & 92 & 169 & & & 212 & 1020 & 161 & 148 & & \\
\hline Conductivity $(\mu \mathrm{S} / \mathrm{cm})$ measured Dec 1992 & & & 150 & & & & & & 280 & 810 & & & & \\
\hline Average Conductivity & 360 & 119 & 136 & 205 & 131 & 226 & 278 & 190 & 274 & 910 & 220 & 206 & 1240 & 675 \\
\hline Silicate $(\mathrm{mg} / \mathrm{L})$ measured Oct/Nov 1988 & & 0.75 & & 0.10 & & 0.22 & 2.2 & & 0.15 & 1.3 & 9.8 & 7.5 & & 3.5 \\
\hline Silicate $(\mathrm{mg} / \mathrm{L})$ measured Nov/Dec1989 & 0.16 & & & 0.12 & 0.16 & 0.22 & 0.39 & 6.5 & 0.37 & 0.55 & 12 & 4.9 & 1.8 & 4.3 \\
\hline Nitrate (mgN/L) & $<0.042$ & n.d. & n.d. & $<0.042$ & $<0.042$ & $<0.042$ & $<0.042$ & $<0.042$ & $<0.042$ & $<0.042$ & $<0.042$ & 0.11 & 2.66 & 0.56 \\
\hline Altitude (m) & 220 & 200 & 190 & 240 & 160 & 200 & 140 & 220 & 99 & 5 & 75 & 10 & 5 & 5 \\
\hline
\end{tabular}

Water $\mathrm{pH}$ and conductivity were measured in the field using portable meters (ICI Stick pH meter and Hanna HI 8633 portable conductivity meter). Silicate concentrations were determined at Macquarie Island Base by colourimetric analysis (Hach model DREL/1C Direct-Reading Environmental Laboratory). Nitrate concentrations were deternined by the Australian Government Analytical Laboratories (Kingston, Tasmania) in lake water samples transported in prepared plastic bottles. The value of 0.042 $\mathrm{mgN} / \mathrm{L}$ was the detection limit for nitrate. $\mathrm{nd}=$ no data.

\section{ACKNOWLEDGEMENTS}

I would like to thank the Australian Antarctic Division for logistic support; Macquarie University for research funding and laboratory facilities; Tasmanian Parks and Wildlife Service for permission to conduct research on Macquarie Island; ANARE expeditioners from the summers of 1988, 1989, 1990, 1992, 1993 for collaboration in the field; Dr Michael Wilson for assistance with fieldwork; and Drs Patricia Selkirk, Jennie Whinam and Herbert Dartnall for fruitful discussions over the years, especially in preparation of this manuscript.

\section{REFERENCES}

Bourrelly, P. \& Manguin, E. 1954: Contribution à la flore algale d'eau douce des Îles Kerguelen. Office de la recherche sciéntifique et technique outre-mer (formerly Memoires de l'Institut Sciéntifique de Madagascar) Series B, vol V: 7--58.

Bunt, J.S. 1954: A comparative account of the terrestrial diatoms of Macquarie Island. Proceedings of the Linnean Society of NSW 79(1-2): 34-57.

Commonwealth of Australia. 1996: Macquarie Island. Nomination by the Government of Australia for inscription on the World Heritage List: 96 pp. + Annexes. Commonwealth of Australia, Canberra.

Evans, A.J. 1970: Some aspects of the ecology of a calenoid copepod, Pseudoboeckella brevicaudata Brady, 1875, on a subantarctic island. ANARE Scientific Reports, series $B, 1$, Zoology: $100 \mathrm{pp}$.
Germain, H. 1937: Diatomées d'une tourbe de l'île Kerguelen. Bulletin de la société française de microscopy vi(1): 11-16.

Germain, H. 1981: Flore des diatomées eaux douces et saumâtres. Boubée, Paris: 444 pp.

John, J. 1983: The Diatom Flora of the Swan River Estuary Western Australia. J. Cramer, Hirschberg: 359 pp.

Keenan, H. 1995: Modern and fossil terrestrial and freshwater habitats on Subantarctic Macquarie Island. Unpubl. PhD thesis, School of Biological Sciences, Macquarie University, Australia.

Krammer, K. \& Lange-Bertalot, H. 1997: Süsswasserflora von Mitteleuropa Bacillariophycede Teil 1-4. Gustav Fischer, Jena: $2500 \mathrm{pp}$.

Le Cohu, R. 1981: Les espèces endemiques de diatomées aux Îles Kerguelen. Colloque sur les ecosystemes subantarctiques. CNFRA 51: 35-42.

Le Cohu, R. \& Maillard, R. 1983: Les diatomées monoraphidées des Îles Kerguelen. Annals of Limnology 19(3): 143-167.

Le Cohu, R. \& Maillard, R. 1986: Les diatomées d'eau douce des 1̂les Kerguelen (à l'exclusion des monoraphidées). Arinals of Limnology 22(2): 99-118.

McBride, T. 1988: Preparing random distributions of diatom valves on microscope slides. Limnology and Oceanography 33(2) 1627-1629.

McBride, T.P. \& Selkirk, J.M. 1999: Palaeolake diatoms on subantarctic Macquarie Island: possible markers of climate change. In John, J. (ed.): Proceedings 15th International Diatom Symposium. (Perth, Australia, 28 September-2 October 1998): 227-236.

McBride, T.P., Selkirk, P.M. \& Adamson, D.A. 1999: Present and past diatom communities on subantarctic Macquarie Island. In Mayama, S., Idei, M. \& Koizumi, I. (eds): 
Proceedings 14th International Diatom Symposium (Tokyo, Japan, 2-8 September 1996): 353-365.

Minchin, R. 1990: Database for ecological community data. Version 2.01 April 1990 Australian National University, Distributed by Anutech Pty. Ltd., Technology Marketing Division, GPO Box 4, Canberra, ACT 2601, Australia.

Pierre, J.F. 1977: Les algues des eaux courantes de l'île de la Possession (Archipel Crozet). Bulletin de la Société Phycologique de France 22: 79-86.

Saunders, K.M., Hodgson, D.A. \& McMinn, A. 2008: Quantitative relationships between benthic diatom assemblages and water chemistry in Macquarie Island lakes and their potential for reconstructing past environmental changes. Antarctic Science 21(1): 35-39.

Selkirk, P.M., Seppelt, R.D. \& Selkirk, D.R. 1990: Subantartic Macquarie Island: Environment and Biology. Cambridge University Press, Cambridge: 285 pp.

Tyler, P.A. 1972: Reconnaissance limnology of Sub-Antarctic Islands I. Chemistry of lake waters from Macquarie Island and the Iles Kerguelen. International. Revue der gesamten. Hydrobiologie und Hydrographie 57(5): 759-778.
Van de Vijver, B. \& Beyens, L. 1999: Freshwater diatoms from Ile de la Possession (Crozet Archipelago, Subantarctica): an ecological assessment. Polar Biology 23: 178-188. [ditto]

Van de Vijver, B., Beyens, L., Gloaguen, J.C. \& Frenot, Y. 1998 : La Flore diatomique de quelques sediments tourbeux holocènes des îles Kerguelen. Annals of Limnology 34(1): $3-11$.

Van de Vijver, B., Frenot, Y. \& Beyens, L. 2002: Freshwater diatoms from Ile de la Possession (Crozet Archipelago, Subantarctica). J. Cramer, Berlin (Bibliotheca Diatomologica Bd 46): $412 \mathrm{pp}$.

Van de Vijver, B., Beyens, L., Vincke, S. \& Gremmen, J.M. 2004 Moss-inhabiting diatom communities from Heard Island, sub-Antarctic. Polar Biology: 27: 542-543.

Van de Vijver, B. \& McBride, T.P. 2006: Gomphonema isabellae Van de Vijver sp. nov., a new freshwater diatom species from sub-Antarctic Macquarie Island (southern Pacific Ocean). Diatom Research 21(2): 441-449.

(accepted 1 September 2009)

\section{APPENDIX 1}

Order of samples in list follows Twinspan ordination based on relative abundance of diatom species in each sample without transformation and including all species

\begin{tabular}{|c|c|c|}
\hline Lake & Date of collection & Particulars of sample \\
\hline "S" Pond & 29 Nov 1990 & Brown slime at southeast margin in $20 \mathrm{~cm}$ depth \\
\hline "S" Pond & 19 Dec 1991 & Algae and submerged moss at east edge in $10 \mathrm{~cm}$ \\
\hline "S" Pond & 29 Feb 1992 & Myriophyllun tips at east edge in $10 \mathrm{~cm}$ \\
\hline "S" Pond & 02 Dec 1989 & Filamentous algae and gelatinous mud in $10 \mathrm{~cm}$ depth at north edge \\
\hline "S" Pond & 01 Dec 1989 & Filamentous algae and moss in $10 \mathrm{~cm}$ depth at south edge \\
\hline Prion Lake & 26 Nov 1990 & Submerged moss at northeast corner in $20 \mathrm{~cm}$ depth \\
\hline Pyramid Lake & 17 Mar 1992 & Rock scrapings at east edge in $10 \mathrm{~cm}$ depth \\
\hline Prion Lake & $31 \operatorname{Jan} 1992$ & Algae and submerged moss from rocks \\
\hline Lake Ainsworth & 10 Nov 1988 & Rock scrapings at west margin near skua club \\
\hline Lake Ainsworth & 08 Mar 1993 & Rock scrapings at southwest edge in $25 \mathrm{~cm}, 1 \mathrm{~m}$ from shore \\
\hline Lake Ainsworth & $06 \mathrm{Dec} 1989$ & Moss at south margin $3 \mathrm{~m}$ from shore in $50 \mathrm{~cm}$ depth \\
\hline Lake Ainsworth & 06 Dec 1989 & Rock scrapings at south margin near southwest corner in $20 \mathrm{~cm}$ depth \\
\hline Lake Ainsworth & 06 Dec 1989 & Rock scrapings at east margin near northeast corner in $20 \mathrm{~cm}$ \\
\hline Lake Ainsworth & 06 Dec 1989 & Submerged moss at east margin near northeast corner in $20 \mathrm{~cm}$ \\
\hline Lake Ainsworth & 06 Dec 1989 & Submerged moss at east margin near northeast corner in $20 \mathrm{~cm}$ \\
\hline Pyramid Lake: & 17 Mar 1992 & Submerged moss from rocks at edge \\
\hline Prion Lake & 01 Mar 1991 & Rock scrapings at northern edge \\
\hline Prion Lake & 21 Dec 1989 & Submerged moss at northern margin in $20 \mathrm{~cm}$ depth \\
\hline Prion Lake & $13 \operatorname{Jan} 1992$ & Submerged vegetation \\
\hline Tulloch Lake & 26 Nov 1990 & Submerged moss at northwest margin in $30 \mathrm{~cm}$ depth \\
\hline Tulloch Lake & 26 Nov 1990 & Rock scrapings at northwest margin in $30 \mathrm{~cm}$ depth \\
\hline Lake Ainsworth & 10 Nov 1988 & Rock scrapings at southeast corner remote from skua club \\
\hline Pyramid Lake & 08 Nov 1988 & Submerged bryophyte Ditrichum strictum \\
\hline Pyramid Lake & 08 Nov 1988 & Rock scrapings \\
\hline Pyramid Lake & 27 Nov 1990 & Submerged moss at northwest edge in $20 \mathrm{~cm}$ depth \\
\hline Tulloch Lake & 31 Oct 1988 & Submerged moss at $30 \mathrm{~cm}$ depth at eastern edge \\
\hline Tulloch Lake & 02 Mar 1992 & Submerged moss and algae at west shore \\
\hline Tulloch Lake & 10 Dec 1992 & Submerged moss at northwest corner in $20 \mathrm{~cm}$ depth \\
\hline Tulloch Lake & 10 Dec 1992 & Rock scrapings at northwest corner in $20 \mathrm{~cm}$ depth \\
\hline Tulloch Lake & 20 Mar 1993 & Myriophyllum at southern end $150 \mathrm{~m}$ east of outlet in $50 \mathrm{~cm}$ depth \\
\hline Tulloch Lake & 20 Mar 1993 & Rock scrapings at southern end $150 \mathrm{~m}$ east of outlet in $50 \mathrm{~cm}$ depth \\
\hline Tulloch Lake & 31 Oct 1988 & Rock scrapings at $20 \mathrm{~cm}$ depth at eastern edge \\
\hline Tulloch Lake & 31 Jan 1992 & Submerged moss and algae at western edge in $20 \mathrm{~cm}$ depth \\
\hline
\end{tabular}




\section{Appendix 1 cont.}

\begin{tabular}{|c|c|c|}
\hline Lake & Date of collection & Particulars of sample \\
\hline Major Lake & 08 Nov 1988 & Submerged bryophyte Ditrichum strictum in $10 \mathrm{~cm}$ depth \\
\hline Major Lake & 23 Nov 1988 & Rock scrapings at site without bird use and $50 \mathrm{~m}$ west of skua club \\
\hline Major Lake & 10 Mar 1993 & Myriophyllum in $30 \mathrm{~cm}$ depth $1.5 \mathrm{~m}$ from shore \\
\hline Major Lake & $10 \operatorname{Mar} 1993$ & Rock scrapings in $30 \mathrm{~cm}$ depth $1.5 \mathrm{~m}$ from shore \\
\hline Major Lake & 11 Dec 1989 & Rock scrapings at water sampling site in $30 \mathrm{~cm}$ depth \\
\hline Major Lake & $11 \operatorname{Dec} 1989$ & Rock scrapings at western margin near outlet in $30 \mathrm{~cm}$ depth \\
\hline Major Lake & 11 Dec 1989 & Rock scrapings at western margin near outlet in $30 \mathrm{~cm}$ depth repeat digestion \\
\hline Major Lake & 27 Nov 1990 & Rock scrapings with moss and algae at western margin in $20 \mathrm{~cm}$ depth \\
\hline Major Lake & 23 Nov 1988 & Rock scrapings from southwest corner near? Skua club \\
\hline Skua Lake & 01 Nov 1988 & Myriophyllum from edge $200 \mathrm{~m}$ east of water sampling site \\
\hline Skua Lake & 14 Dec 1989 & Myriophyllum at shoreline near water sampling site in $30 \mathrm{~cm}$ depth \\
\hline Skua Lake & $14 \operatorname{Dec} 1989$ & Rock scrapings near water sampling site at shoreline in $20 \mathrm{~cm}$ depth \\
\hline Skua Lake & $14 \operatorname{Dec} 1989$ & Myriophyllum at shoreline near outlet in $30 \mathrm{~cm}$ depth \\
\hline Skua Lake & 01 Nov 1988 & Rock scrapings from edge $200 \mathrm{~m}$ east of water sampling site \\
\hline Skua Lake & 01 Nov 1988 & Myriophyllum near water sampling site at western end of south margin \\
\hline Skua Lake & 01 Nov 1988 & Rock scrapings near water sampling site at western end of south margin \\
\hline Ifould Lake & 13 Dec-1.989 & Submerged moss at eastern edge near outlet in $20 \mathrm{~cm}$ depth \\
\hline Ifould Lake & 13 Dec 1989 & Rock scrapings at western margin near outlet in $10 \mathrm{~cm}$ depth \\
\hline Green Gorge Tarn & 11 Mar 1993 & Myriophyllum in $20 \mathrm{~cm}$ depth \\
\hline Ifould Lake & 13 Dec 1989 & Myriophyllum at southeast margin on shore \\
\hline Square Lake & 10 Dec 1992 & Rock scrapings at eastern end of northern edge in $15 \mathrm{~cm}$ depth \\
\hline Square Lake & $10 \mathrm{Dec}-992$ & Myriophyllum at eastern end of northern edge in $15 \mathrm{~cm}$ depth \\
\hline Square Lake & 10 Dec 1992 & Rock scrapings at east end of northern edge in $15 \mathrm{~cm}$ depth \\
\hline Square Lake & 10 Dec 1992 & Myriophyllum at east end of northern edge in $15 \mathrm{~cm}$ depth \\
\hline Square Lake & 26 Nov 1990 & Myriophyllum at surface at southeast corner \\
\hline Square Lake & 26 Nov 1990 & Rock scrapings at southeast corner in $30 \mathrm{~cm}$ depth \\
\hline Square Lake & 01 Mar 1991 & Myriophyllum at northeast edge. \\
\hline Green Gorge Tarn & 04 Nov 1988 & Myriophyllum at middle of southeast edge \\
\hline Green Gorge Tarn & 14 Dec 1989 & Myriophyllum east end of northern margin on surface \\
\hline Green Gorge Tarn & 28 Nov 1990 & Myriophyllum at surface at eastern margin \\
\hline Brothers Lake & 31 Jan 1992 & Myriophyllum at northern edge in $20 \mathrm{~cm}$ depth \\
\hline Green Gorge Tarn & 30 Nov 1991 & Myriophyllum \\
\hline Square Lake & 01 Mar 1991 & Rock scrapings at northeast edge \\
\hline Brothers Lake & 03 Nov 1988 & Myriophyllum and algae at northeast edge \\
\hline Brothers Lake & 03 Nov 1988 & Myriophyllum at northern margin near northeast corner \\
\hline Brothers Lake & 03 Nov 1988 & Rock scrapings from mid northern margin \\
\hline Brothers Lake & 28 Nov 1990 & Myriophyllum at surface at eastern margin \\
\hline Brothers Lake & 17 Dec 1991 & Floating algae and submerged moss at northern edge in $20 \mathrm{~cm}$ depth \\
\hline Brothers Lake & 16 Mar 1992 & Myriophyllum at northern edge in $20 \mathrm{~cm}$ depth \\
\hline Brothers Lake & 21 Dec 1989 & Rock scrapings at northern margin in $30 \mathrm{~cm}$ depth \\
\hline Brothers Lake & 21 Dec 1989 & Myriophyllum at northern margin in $50 \mathrm{~cm}$ depth and $2 \mathrm{~m}$ from edge \\
\hline Brothers Lake & 21 Dec 1989 & Myriophyllum at surface near water sampling site \\
\hline Brothers Lake & 28 Nov 1990 & Rock scrapings at northwest margin in $20 \mathrm{~cm}$ depth \\
\hline Duck Lagoon & 13 Nov 1988 & Rock scrapings from eastern edge \\
\hline Duck Lagoon & 26 Nov 1990 & Rock scrapings at northern site in $50 \mathrm{~cm}$ depth \\
\hline Duck Lagoon & 01 Dec 1989 & Bottom detritus at southeastern margin $2 \mathrm{~m}$ from edge in $50 \mathrm{~cm}$ depth \\
\hline Duck Lagoon & 01 Dec 1989 & Filamentous algae in about $30 \mathrm{~cm}$ depth and $2 \mathrm{~m}$ from edge of southeastern margin \\
\hline Duck Lagoon & 26 Nov 1990 & Myriophyllum at surface at southern site \\
\hline Duck Lagoon & 28 Feb 1991 & Floating vegetation at northern edge \\
\hline Duck Lagoon & 22 Dec 1989 & Myriophyllum at southwest shore on surface \\
\hline Duck Lagoon & 22 Dec 1989 & Myriophyllum at northeast shore on surface \\
\hline Duck Lagoon & 22 Dec 1989 & Myriophyllum at eastern shore on surface \\
\hline Duck Lagoon & 22 Dec 1989 & Myriophyllum at northwestern shore $3 \mathrm{~m}$ from at edge in $80 \mathrm{~cm}$ depth \\
\hline Duck Lagoon & 01 Dec 1989 & Rock scrapings from $30 \mathrm{~cm}$ depth near at northern shore \\
\hline Duck Lagoon & 26 Nov 1990 & Rock scrapings at southern site in $50 \mathrm{~cm}$ depth \\
\hline
\end{tabular}


Appendix 1 cont.

\begin{tabular}{lll}
\hline Lake & Date of collection & \multicolumn{1}{c}{ Particulars of sample } \\
\hline Duck Lagoon & 02 Feb 1991 & Rock scrapings at southern bank. \\
Duck Lagoon & 22 Dec 1989 & Sediment at northeastern margin near edge in $30 \mathrm{~cm}$ depth \\
Duck Lagoon & 26 Nov 1990 & Botrom detritus in $30 \mathrm{~cm}$ depth \\
Handspike Pond & 27 Nov 1989 & Marginal vegetation in about $10 \mathrm{~cm}$ depth at southwestern edge \\
Handspike Pond & 27 Nov 1989 & Fibrous mud at edge in $30 \mathrm{~cm}$ depth \\
Langdon Point Pond & 26 Dec 1989 & Peat scrapings at western margin in $20 \mathrm{~cm}$ depth \\
Langdon Point Pond & 26 Dec 1989 & Rock scrapings in $40 \mathrm{~cm}$ depth near eastern shore \\
\hline
\end{tabular}


APPENDIX 2

Diatom species observed in Macquarie Island lakes and ponds

\begin{tabular}{|c|c|}
\hline Achnanthes clevei Grunow & Navicula rhyncocephala Kützing \\
\hline Achnanthes inflata Kützing & Navicula subrhyncocephala Hustedt \\
\hline Achnanthes lapponica var. ninkei (Guermeur \& Manguin) Reimer & Naviculadicta elorantand Lange-Bertalot \\
\hline Achnanthes linearis W. Smith & Naviculadicta seminulum Grunow \\
\hline Achnanthidium minutissimum (Kürzing) Czarnecki & Neidium affine Ehrenberg \\
\hline Achnanthidium modestiforme (Lange-Bertalot) Van de Vijver & Neidium iridis (Ehrenberg) Cleve \\
\hline Adlafia bryophila (Petersen) Lange-Bertalot & Nitzschia aff. linearis (Agardh) W. Smith \\
\hline Amphora coffeaeformis Agardh & Nitzschia dissipata (Kützing) Grunow \\
\hline Amphora copulata (Kützing) Schoeman \& Archibald & Nitzschia frustulum (Kützing) Grunow \\
\hline Amphora veneta Kützing & Nitzschia gracilis Hantzsch \\
\hline Aulacoseira distans (Ehrenberg) Simonsen & Nitzschia inconspicua Grunow \\
\hline Brachysira exilis (Kützing) Round \& Mann & Nitzschia vermicularis (Kützing) Grunow \\
\hline Caloneis bacillum (Grunow) Mereschkowsky & Nupela chilensis (Krasske) Lange-Bertalot \\
\hline Caloneis marnieri Manguin & Pinnularia acoricola Hustedt \\
\hline Cocconeis neothumensis Krammer & Pinnularia acidicola var. elongata Van de Vijver \& Le Cohu \\
\hline Cocconeis placentula Ehrenberg & Pinnularia appendicula (Agardh) Cleve \\
\hline Cymbella gracilis (Rabhenhorst) Cleve & Pinnularia borealis var. scalaris (Ehrenberg) Rabenhorsr \\
\hline Cymbella microcephala Grunow & Pinnularia gibba Ehrenberg \\
\hline Diadesmis arcuata (Heiden) Lange-Bertalot & Pinnularia lata Brébisson \\
\hline Diadesmis subantartica Le Cohu \& Van de Vijver & Pinnularia microstauron (Ehrenberg) Cleve \\
\hline Diatomella balfouriana Greville & Pinnularia obscura Krasske \\
\hline Diploneis subovalis Cleve & Pinnularia subantarctica var. elongata (Manguin) Van de Vijver \\
\hline Encyonema vulgare Krammer & \& Le Cohu \\
\hline Eolimna minima (Grunow) Lange-Bertalot & Pinnularia viridis Nitzschia \\
\hline Eunotia aff. subarcuatoides Alles, Nörpel \& Lange-Bertalot & Planothidium aueri (Krasske) Lange-Bertalot \\
\hline Eunotia curvata (Kützing) Lagerstedt & PLanothidium cyclophorum (Heiden) Van de Vijver \\
\hline Eunotia paludosa Grunow & Planothidium deliculatum (Kützing) Round \& Bukthiyarova \\
\hline Fragilaria capucina var. gracilis (Kützing) Lange-Bertalot & Planothidium lanceolatum (Brébisson) Lange-Bertalot \\
\hline Fragilaria capucina var, rumpens (Oestrup) Hustedt & Planothidium quadripunctatum (Oppenheim) Sabbe \\
\hline Fragilaria capucina var, vaucheriae (Kützing) Lange-Bertalot & Psammothidium abundans (Manguin) Bukthiyarova \& Round \\
\hline Fragilaria exigua Grunow & Psammothidium confusum (Manguin) Van de Vijver \\
\hline Fragilaria pulchella (Ralfs) Lange-Bertalot & Psammothidium confusum var. atomoides (Manguin) Van de \\
\hline Frustulia rhomboides (Ehrenberg) de Toni & Vijver \\
\hline Frustulia subantarctica Van de Vijver \& Beyens nov. spec. & Psammothidium germainii (Manguin) Sabbe \\
\hline Geissleria paludosa (Hustedt) Lange-Bertalot & Psammothidium incognitum Van de Vijver \\
\hline Gomphonema affne Kützing & Psammothidium manguinii (Hustedr) Van de Vijver \\
\hline Gomphonema intricatum Kützing & Psammothidium oblongellum (Oestrup) Van de Vijver \\
\hline Gomphonema stonei Reichardt & Psammothidium stauroneioides (Manguin) Bukthiyarova \\
\hline Gomphonema subantartica Van de Vijver \& Beyens nov. spec. & Psammothidium therezienii (Le Cohu \& Maillard) Van de Vijver \\
\hline $\begin{array}{l}\text { Gomphonema tumidum (Skvortzov \& Meyer) Lange-Bertalot } \& \text { } \\
\text { Reichardt }\end{array}$ & $\begin{array}{l}\text { Stauroforma exiguiformis (Lange-Bertalot) Flower, Jones \& } \\
\text { Round }\end{array}$ \\
\hline Lecohuia geniculata (Germain) Lange-Bertalot & Stauroneis anceps Ehrenberg \\
\hline Luticola mutica (Kützing) Mann & Stauroneis gracilior (Ehrenberg) Reichardt \\
\hline Mastogloia recta Hustedt & Stauroneis kriegeri Patrick \\
\hline Navicula cincta (Ehrenberg) Kützing & Stauroneis phoenicenteron Ehrenberg \\
\hline Navicula cincta var. heuflerii (Grunow) Grunow & Staurosira alpestris (Krasske ex Hustedt) Van de Vijver \\
\hline Navicula gregaria Donkin & Staurosira circula Van de Vijver \& Beyens \\
\hline Navicula hustedtii Krasske & Staurosira jolinae Van de Vijver \\
\hline Navicula lanceolata (Agardh) Ehrenberg & Staurosira leptostauron Ehrenberg \\
\hline Navicula muticopsis Van Heurck & Staurosira pinnata Ehrenberg \\
\hline Navicula pseudocitris Manguin. & Surirella angusta var. constricta Hustedt \\
\hline Navicula pseudoscutiformis Hustedt & Surirella linearis W. Smith \\
\hline Navicula pupula Kützing & Surirella ovata Kützing \\
\hline
\end{tabular}


APPENDIX 3

Pooled relative abundances of all taxa in each lake

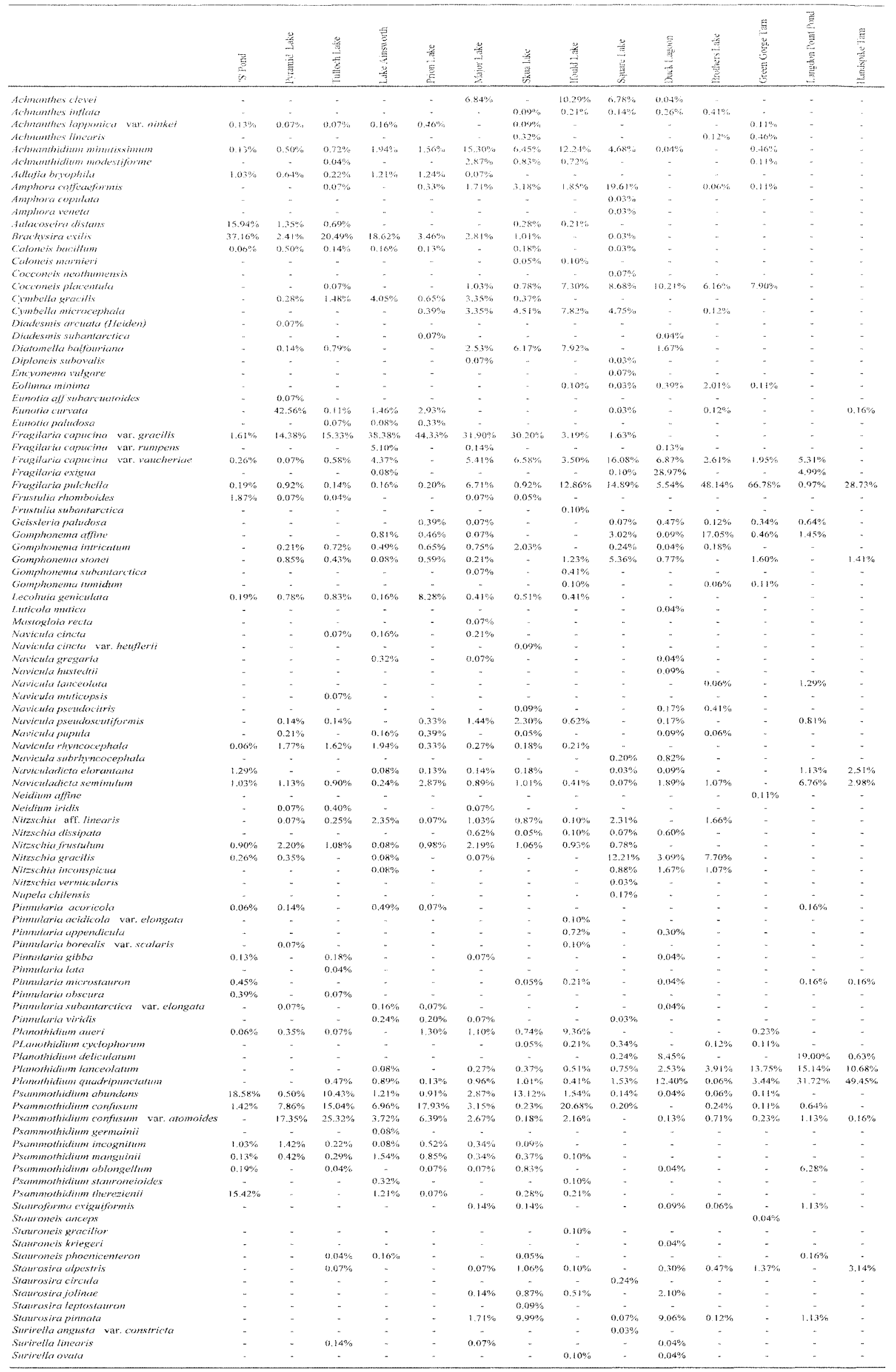

